\title{
Relationship between saving and investment pattern and orientation towards finance among working women in the universities of Saudi Arabia
}

\author{
Wardah Abdulrahman Abdullah Bindabel ${ }^{\mathrm{a}}$ and Ansa Savad Hamza Salim ${ }^{\mathbf{b}^{*}}$
}

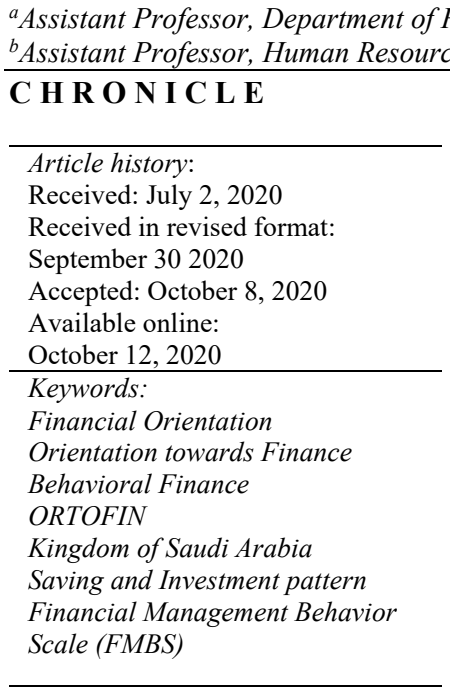

ance, College of Business Administration, Prince Sattam Bin Abdulaziz University, Saudi Arabia anagement, College of Business Administration, Prince Sattam Bin Abdulaziz University, Saudi Arabia A B S T R A C T
The main objective of the study was to find out the relationship between saving and investment
pattern and orientation towards finance among the working women at the universities of Saudi
Arabia. Orientation towards finance (ORTOFIN) is one's attitude towards effectively managing
financial activities. This attitude is backed by individual behavior toward financial management.
ORTOFIN scale was made as a construct to measure the behavioral dispositions of individuals that
are connected to their behavior patterns towards finance and orientations. The data was collected
using the ORTOFIN scale which was constructed and used in the European population as well as
validated using standard procedures into the Asian population. The present study concentrates on the
working women at the Universities of Saudi Arabia. The data collected from 192 women employees
of different Universities in Saudi Arabia. This study states there is a significant positive relationship
among the saving and investment pattern and orientation towards finance among the working women
at the universities of Saudi Arabia. The finding of the study revealed Financial Management Behavior
act as a major contributor to the orientation towards finance and the factor of personnel planning is
another significant contributor towards ORTOFIN. (C) 2021 by the authors; licensee Growing Science, Canada

\section{Introduction}

In total, the significance of socioeconomic status relates to the apprehension happening towards sustainable development and growth among the global markets. The development of different nations looks forward to the investment behavior of their citizens to a greater extend. The salaried class of people acts as a change agent and is expected to improve the standard of living of an economy. The significant improvement will indeed reflect on the economic growth of a nation. Saudi Arabia is enduring into several innovative implementations as part of Vision 2030. Strategic plans are focusing on the development of all sectors of the country. Employed citizens are accountable to contribute back to society. They need to invest wisely and distribute their income in the most reliable sources. The demand for product and services let the salaried people spend more on a different market. Today, many studies in the Asian population reveal a drastic change in the salaried class's spending habits due to various economic crises and uncertainties, such as job insecurity. Most economies get disturbed due to poverty, gender inequality, unemployment, etc. Employment is a potential solution for all these complications. Many research studies related to individual financial behavior started long before the emergence of Behavioral Finance. The studies associated with Behavioral Finance have started as a unique discipline. This discipline has opened many research areas of investigation related to empirical nature in connection with behavioral finance. Few studies undertaken in the area of Savings and investment include taxation, micro* Corresponding author. Tel.: +966557560540 E-mail address: a.salim@psau.edu.sa (A. Savad Hamza Salim) 
financing, gambling or the stock market, financing, etc. with economic and financial behavior. Various related topics of investment behavior have been researched, but there is limited literature to determine the relationship between Investment behavior and orientation towards finance. There is no shortage of literature in this particular research in the Middle East, especially in Saudi Arabia. This research specifically focuses on the ORTOFIN among the working Saudi women citizens.

\section{Literature Review}

People typically invest their money where they will get the best returns and the security of their assets. Investment activities are vital for the progress and growth of a society. Individual investors have a critical part in the financial sector due to the large share of their savings accumulated in the state. The move to implement an investment is often focused on behavioral finance. Term investment involves using funds in all financial securities and assets to receive a return or value of money (Gitman et al. 2013). It has been the wealth transfer to the money-generating product prospectively. Investment is a capital investment that produces the resources required for different sectors of the economy. Investment evaluation is a challenging job, requiring significant skills and experience to assess the choices available. Besides that, a smart investment decision will lead to higher returns and satisfaction levels generally (Gitman et al., 2013). However, it seems challenging for women to evaluate the different choices for seeking suitable investment opportunities due to lack of knowledge, although people do not even understand where to invest and what the investment will be (Lee \& Shin 2018). Therefore, it is essential to evaluate investors' actions to recognize different benefits and drawbacks of women's investment. Women are nowadays stable financially. Women are actively investing their investments by evaluating different variables, such as the level of risk involved in investing, the impact of friends and family members, and the desire to invest in new and creative investment opportunities (Lee \& Shin 2018). This section presents the idea of women's investment activity and trends and provides a thorough review of previous scientific investigations on women's investment behavior.

\subsection{Global investment Behavior of Women}

Research by Bertrand, 2020, utilizes large-scale questionnaires as a tool to investigate women gaps in investment decisions. The qualitative survey query is perceived as a proper measurement of the investment risk. It predicts actual risk-taking actions in the experiment, even after testing specific, measurable characteristics (Bertrand, 2020). It is worth noting that, while current research investigating gender disparities in financial risk behavior that uses specific techniques and tactics, they almost all suggest that females' members of the society are much more risk-averse investors when compared to males. A recent study suggests that women prefer less risky investments and still receive higher yields on their financial assets than men (Dohmen et al., 2017). Many of these analyses do not make investment decisions through gender when mitigating possible gender gaps in expertise. Consequently, Esfandyar et al. (2017) assessed the risk-taking conduct of women investing in mutual funds while monitoring investors' essential investment awareness. That used a United States Survey of 1900 random sample on mutual fund holders; the findings revealed that women's mutual funds are partly due to the institutional gaps in women's financial and investment awareness (Esfandyar et al. 2017). Additionally, women take fewer precautions than men in their financial investment choices, even when accounting for monetary or knowledge on investment, although the impact of gender on risk-taking decreases when investor financial or investment information is regulated in the regression. The varying levels of investment expertise between gender groups may partly explain the significant degree of women's risk. Denoting gender is very important since the trading conduct of men and women varies, and so their effect on market valuations varies. Recent research in the United States and international markets indicates that individual traders have behavioral biases in their transactions that affect asset prices, returns, and the overall market. Nevertheless, these studies do not explicitly suggest which gender has more prejudice (Esfandyar et al. 2017). For example, several current studies indicate that specific investors are overaggressive but will not show whether men or women may be more optimistic about their investment skills and capabilities.

\subsection{Middle East Women Investment Behavior}

Today, there are very few reports that focus specifically on women's investment behavior. In contrast, none focus on the top investment obstacles hindering women's involvement in investing, and the primary causes that drive them to invest more. In comparison, most research on women's investment behavior concentrates on developed markets, especially the United States. On the other hand, few investigations have been carried out in developing markets and very few in the Arab world (Kanze et al., 2020). As per the report by Fund (2017), women's sensible approach is more prominent when making long-term investment decisions such as retirement funds. Nevertheless, this was partially due to decreased wealth accrued, considering that they had lower wages than their male colleagues. Nonetheless, the findings were not substantially different after adjusting demographic and economic factors (Charness\& Gneezy, 2007). Women in the Middle East also were found to follow a risk-aversive approach irrespective of profession, expertise, and level of competence. There was proof that a woman investor would often take a costaversive approach and encourage her clients to prefer lower risk and lower return investments. Nevertheless, women's strategy tends to be consistent with the principle of risk and return relationships, as proposed (Cabeza-García et al. 2019). They claim that the anticipated return of security has increased as the probability of loss decreases, and vice versa. Women investors were found to prefer more assurance and lower returns to trading (Roszkowski \& Grable, 2010). Nevertheless, risk and uncertainty are viewed and perceived as a risk and an opportunity to earn greater yields in the long term. 


\subsection{Investment Behavior of Saudi Women}

To expand and broaden the increasing discourse on gender disparities in investment behavior to include women investors from diverse cultures, this research focuses mainly on examining women's investment behavior in Saudi Arabia Universities. Men in all areas do not necessarily surpass women: they are much more likely than men to provide a strategy and maintain track of the information (Cabeza-García et al. 2019). Nonetheless, in several countries, such as Saudi Arabia, there are places where women exhibit limitations, including making ends meet and investing and the choice and keeping of financial goods. The evidence available, albeit restricted to a limited number of states, means that women and their capacity to make life easier and save are partly linked to the disparity in socioeconomic differences between the sexes.

\subsection{Personal Financial Planning}

Personal Financial Planning (PFP) defines personal financial objectives and funds, develops a financial strategy, and makes personalized suggestions (either expressed or implied) that help clients achieve these goals when enforced. This procedure may facilitate the design of recommendations or the tracking or modify of the commitment. Personal Financial Planning provides definitive guidelines and sets enforceable criteria for members offering Personal Financial Planning information to help them meet their professional obligations. Personal Financial Planning requires measures designed to allow the Member to achieve the primary goal (Munohsamy, 2015). Personal Financial Planning knowledge is critical, especially when researching this. Also, it involves gathering guidelines in the context of a specification and other necessary instructions, which provides a context related to the thorough understanding of the concept and definitions. The specifications of the assertion should be described using the term. If the requirement specifies that a representative "should" take action, such action shall be necessary unless the case's predominant details determine differently. Doda and Fortuzi (2015) revealed in their study that customers are more likely to pursue the expertise of a financial adviser than 14 other qualified stakeholders in financial stability, like banking while searching for detailed personal financial planning (Doda \& Fortuzi 2015). Murphy and Yetmar (2010) used poll information to demonstrate that students decide that they'll need to make personal financial planning; they spend much more time monitoring and developing plans. That attempt is related to higher economic power (Murphy \& Yetmar, 2010). Doda and Fortuzi (2015) observed a change in attitudes among women who now understand that comprehensive long-term financial planning is crucial to effective money planning. A single advisor can incorporate all of their financial requirements into a detailed plan more successful. Women who want to gain financial freedom when they retire or preserve properties that are mortgaged when they die risk the consequences of not having the resources to do so if no personal financial planning has been carried out (Doda \& Fortuzi 2015). The personal financial planning is a step by step application which leads to the implementation of risk management strategies at the individual level. This will include a more detailed description of the risks that women face, the correct prioritization of those risks, and the successful management of those risks (Munohsamy, 2015). It was observed that individuals appear to invest additional time handling smaller threats that they face but do not spend quality time on risks that impact their entire economic well-being. Munohsamy (2015) indicates that the resources for investment advisors to be used in the personal financial planning process will increase complexity and that business planners' expertise will also have to improve.

\subsection{Investment behavior of working women}

Research has been carried on women's investment behavior in terms of maturity, education, income, resources, marital status, and gender; Steelyana (2012) showed that working women prefer to take lowered investment risks. She also found that married women would prefer a retirement account to their investment market (Steelyana, 2012). Rekha and Vishnupriya (2019) found that more investment choices could trigger an overload of knowledge. This will confuse with making the right investment decision. They also found that individuals can be narcissistic and overstate their knowledge and expertise in making an investment decision (Rekha \&Vishnupriya 2019). Steelyana (2012) found that most women are not informed of investments, mutual funds, and savings accounts. Understanding of these investments is strongly associated with education and work orientation. Ramanujam \& Leela (2016) found that perhaps the attitude towards risk changes with time. The willingness and confidence to take risks are closely related to customers' business life (Ramanujam \& Leela 2016). Atchyuthan and Yogendrarajah (2017) concluded that if working women are given various investment choices, they would like to choose between a middle part and a high or low significance (Atchyuthan \& Yogendrarajah, 2017). Ramanujam and Leela (2016) research also focused on expectations of earnings efficiency, clarity of the mechanism for preparing accounts, independence of auditors, consumers, and financial information (Ramanujam \& Leela 2016). He observed that accounting information among working women guarantees the right investment choice rather than a quantitative approach in the long term. Asandimitra et al., (2019) examined the investment behavior of salaried women workers with various investment choices and the investment selection process factors. It found that salaried women frequently find both protection and high profits (Asandimitra et al., 2019). Chowdhury (2009) carried out a summary of the financial awareness and investment strategies of women in the workforce in Chittagong intending to identify the financial education and investment behavior of these women in Kerala while using qualitative and quantitative data qualitatively (Chowdhury 2009). The analysis revealed that the investment conducts of women who are working are culturally conservative. Investment behavior depends on the appropriate level of the participant. Many people speak of long-term investment. Women prefer to save for social welfare and long-term reasons. On average, women are found to be more risk-averse than men (Chowdhury, 2009). Based on these investment studies, working women's financial 
decision-making and investment behavior are focused not only on the growing preference but also on aspects like financial intuition, expertise in investment activities, financial priorities, and the risk tolerance of each woman investor. Gender does not have an impact on investment decisions. Still, other factors have become some of the main factors that affect investor behavior, such as financial insight, understanding of investment strategies, experience in continuing investment activities, and financial objectives (Alrabadi et al., 2018). Investment conduct could then be very special to each entity and personalized based on their specific financial objectives.

\subsection{Financial Management Behavior Scale}

Many studies in financial management behavior scales exist, and they researched different dimensions using different demographics (Sulphey \& Nisa, 2014). In few types of research, scales are connected with the elements of managing financial aspects such as the attitude toward debt (Lea e.t al., 1995), investor behavior in the stock market (Wärneryd, 2001), savings (Wärneryd, 1999), gambling (Walker, 1995), of the respondents to a greater extend. The knowledge about finance is not ensuring appropriate behavior in saving or investment (Perry, 2005). According to Bernheim et al. (2001), education about finance utilization is critical to maintaining personal savings. Also, in their study, they found there is a relationship between higher savings and net worth. Financial Knowledge and financial behavior are having a considerable impact (Courchane, 2005). According to Sood and Kaur (2015), many factors affect the investment behavior or bank deposit of people tax, safety, and high returns.

\subsection{Middle-east studies related to investment behavior}

Salim, et al. (2019), in their study, examined Omani teachers' investment behavior and found that most of them prefer investment than spending on luxurious items. This study also revealed that they make thoughtful decisions while investing, especially in the case of the long-term. Salim \& Khan (2020), in their research on the factors influencing investment patterns among Omani working women, found they give more importance to the education of their children and future safety and security while making their investments. But minimal studies focus on the relationship between demographics and financial behavior, especially in women of Saudi Arabia or the Middle- East in common. The tool identified is relevant with highly practical implications is ORTOFIN, which determines the relationship between financial behaviors, financial education, and different financial management areas. According to Sulphey and Nisa (2014), ORTOFIN is a highly useful tool used to understand the population's categories. A direct relationship is between financial orientation, and consumer behavior is found by a research study by Faber \& O'Guinn (1988). Many relevant research studies scrutinized the relationship between financial behavior and demographics and saw ORTOFIN as a valid instrument that can be used to find out different behavioral patterns related to finance (Loix et al., 2005; Sulphey and Nisa, 2014; Chen \& Volpe, 1998). At the same time, limited studies have examined in the Middle East, especially in Saudi Arabia. According to Perry (2005), financial knowledge will not guarantee assertive financial behavior among people. Some people with limited knowledge tent to borrow at a significantly higher level, leading to a higher risk of financial issues (Lusardi \& Mitchell, 2007). Joo (2008), in his study, stated that the knowledge of financial income and a high level of confidence in finance would arise when people have individual income. Financial knowledge exists as a significant element of financial wellness. According to Bernheim et al. (2001), there is a high degree of relationship between saving rates and net worth. They also stated financial education plays a significant role and a potent tool to trigger individual savings.

\subsection{Why is this particular Scale used?}

The scale used in this research is ORTOFIN, which is explicitly constructed to find out individuals with high scores, which will lead to substantial financial orientation. This scale is further looking into the ability of individual achievement towards using money. A high score represents one's comprehensive awareness towards financial aspects, especially his investments and saving, Loix et al., (2005). A high score also shows the behavior of individuals who were having different varieties of investments. According to Loix et al., (2005), there is a positive relationship between ORTOFIN and customer service. Besides, they have a habit of using bank cards such as debit/ credit continuously. Several studies attempted to study the financial behavior and related demographics but substantially fewer studies connected with Saudi Arabia and Middle-east as a whole. This study is particularly is trying to address and fill the gap in the literature. The proposed research identified a few objectives based on the review of literature are as follows:

1. To study the relationship between ORTOFIN (ORTOFIN) and Financial Management Behavior among Salaried Saudi Women in the Universities of Saudi Arabia.

2. To study the relationship between ORTOFIN and Financial Information of Saudi Working Women.

3. To study the relationship between ORTOFIN and Personnel Planning of Saudi Working Women.

4. To identify the measures for fostering Saving and Investment behavior among Saudi Working Women.

5. To give suggestions to improve the Saving and Investment behavior of Salaried women in the Universities of Saudi Arabia

Based on these objectives, the hypotheses for the study are as stated below:

H10: There is no significant contribution towards ORTOFIN and Financial Management Behavior of Saudi Working Women. H20: There is no significant relationship between ORTOFIN and Financial Information of Saudi Working Women. 


\section{Methodology and Methods}

This particular study implements an exploratory research design as the research problem is not clearly explained. This research population includes working Saudi women at the Universities, and few Saudi working males at the Universities were collected to compare the data. After an in-depth review of the literature, a survey questionnaire was adopted with appropriate variables. The data collected using the primary data collection method. A survey questionnaire was used through google forms and sent to employed women in different Saudi Arabia universities. The collected data was analyzed using statistical techniques like descriptive statistics, correlation analysis, t-test, ANOVA, etc. An in-depth review of the literature was done to identify an appropriate survey instrument for individual variables. For measuring the Saving and Investment pattern, ORTOFIN scale developed by Loix et al. (2005) was used. It was tested and validated in the Indian context by Sulphey and Nisa (2014). Many other studies related to investment behavior confirmed cross-national validity for the scale. ORTOFIN is divided into two major factors, (a) Financial Information and (b) Personal Financial Planning. If there is a high score of ORTOFIN then that means a stronger financial orientation.

1. I never read the financial pages of my newspaper.

2. I try to keep track of general economic trends.

3. I am not attracted to the financial part of life.

A revised twelve item Questionnaire developed by Xiao and Dew (2011) was used to measure the Financial Management Behavior Scale (FMBS). Many studies ensured the validity of the FMBS measuring scale in other countries. The scale is divided into four sections: cash management, credit management, savings and investments, and insurance with seventeen items in the questionnaire. They revised the questionnaire and got shortened to 15 items. We used the shortened questionnaire. Sample questions include the following:

1. Comparison shopped when purchasing a product or service.

2. Paid all your bills on time

3. Kept a written or electronic record of your monthly expenses

The data collection was done through Online Google forms among Saudi working women. Simultaneously, a sample of ten expatriate respondents was used to compare the same and validity of the questionnaire. Demographic data was added along with items under study. The respondents were asked to indicate their responses based on the degree of agreement to disagreement on a five-point Likert scale. The current study used a sample size of 192 respondents.

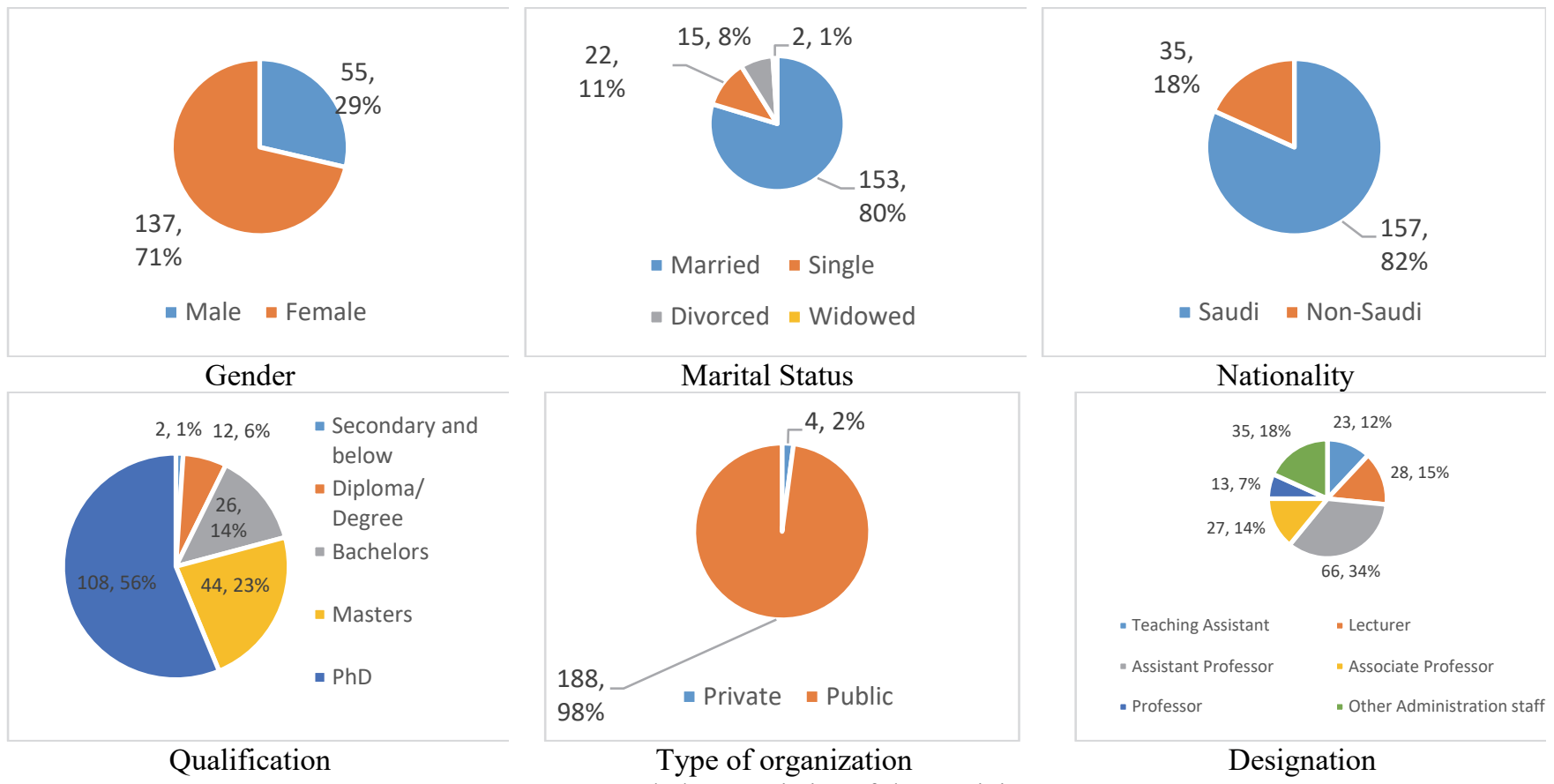

Fig. 1. Personal characteristics of the participants

Twenty-eight percent of the participants were male, and seventy-one percent were females. The study focuses on Working women, so the majority population was women. A sample of males was used to understand their degree of agreement and disagreement towards the factors under study. Eighty percent of the respondents were married, and twelve percent were unmarried, seven percent stated as they are divorced, and one percent widowed. Eighty-two percent of respondents were Saudi 
working nationals, and eighteen percentage non-Saudi participated in the study. Among the respondent, one percent of the respondents were secondary or below. Six percent of the respondents were diploma or degree holders, thirteen percent master holders, and fifty-six percent had Ph.D. The majority of the respondents, 98 percent, are from the Public sector, and two percent of the respondents are from private organizations. Twelve percent of the respondents are teaching assistants, fourteen percent lecturers, thirty-four percent assistant professors, fourteen percent associate professors, six percent of Professors, and eighteen percent of other admin related positions.

\section{Findings}

The data collected through the survey were analyzed with quantitative data analysis. The survey was conducted using an online questionnaire in Google forms a total of 192 respondents actively involved in the survey. The data thus collected were tabulated and analyzed for extracting the results of the study. The below tables explained the detailed information of results.

Table 1

Group Statistics

\begin{tabular}{lllll}
\hline Items & Gender & $\mathrm{N}$ & Mean & Standard Deviation \\
\hline Financial information & Male & 55 & 12.36 & 1.778 \\
& Female & 137 & 13.66 & 2.763 \\
Personal planning & Male & 55 & 8.182 & 1.9350 \\
& Female & 137 & 8.584 & 2.2480 \\
ORTOFIN & Male & 55 & 20.55 & 2.201 \\
& Female & 137 & 22.25 & 4.074 \\
FMBS & Male & 55 & 40.64 & 6.620 \\
& Female & 137 & 41.55 & $7.929 * *$ \\
\end{tabular}

** significant at 0.01 level

In this study for analysis purposes, the continuous variable is grouped into nominal variables using group statistics mean and standard deviation. Also, the t-values were found to identify which variables are significant. The Group Statistics about variables understudy include Financial information, Personal Planning, ORTOFIN, and Financial Management Behavior Scale were calculated. The mean, Standard deviation, and t-value of the variables were tabulated in Table 1. The highest Score of Mean is with Financial Management Behavior Scale (FMBS) with Females 41.55. The consistent score is with Financial Information of males with less spread and far distributed from the Mean value, i.e., 1.778. Financial Information and ORTOFIN are significant were as Personal Planning, and FMBS are not substantial, as shown in Table 1 . The t value is significant at 0.01 level, financial information with 3.230 and ORTOFIN 2.929, and Personal planning and FMBS are not significant as their t-values are 1.164 and 0.752 , respectively. The correlation between different variables under study is presented in Table 2.

\section{Table 2}

Correlation between variables

\begin{tabular}{|c|c|c|c|c|c|c|c|}
\hline Variables & Financial information & Personal planning & ORTOFIN & FMBS & Age & Experience & Qualification \\
\hline Financial information & 1 & & & & & & \\
\hline Personal planning & $.216^{* *}$ & 1 & & & & & \\
\hline ORTOFIN & $.822^{* *}$ & $.734^{* *}$ & 1 & & & & \\
\hline FMBS & $.413^{* *}$ & $.621^{* *}$ & $.650^{* *}$ & 1 & & & \\
\hline Age & .059 & -.040 & .017 & .041 & 1 & & \\
\hline Experience & .089 & -.091 & .009 & .041 & $625^{* *}$ & 1 & \\
\hline Qualification & .127 & .127 & .162 & .161 & $.233^{* *}$ & $.220^{* *}$ & 1 \\
\hline
\end{tabular}

** Correlation is significant at the 0.01 level (2 tailed)

*Correlation is significant at the 0.05 level ( 2 tailed)

The data has been analyzed with correlation as well as multivariate regression with the help of the Statistical Package for Social Science (SPSS). The collected data was analyzed to find out the relationship between all the variables under study. This revealed clear information towards the contribution of variables on ORTOFIN. Karl Pearson Correlation was conducted among the variables. There exists a significant positive correlation among ORTOFIN, Financial Information ( $\mathrm{r}=.822)$, and Personal Planning $(\mathrm{r}=0.734)$, which is significant at 0.01 level. Moderate positive correlation among FMBS, Personal Planning ( $\mathrm{r}=0.621)$, and ORTOFIN ( $\mathrm{r}=650)$, which is also at 0.01 level. There exists a less positive correlation among age, financial information, ORTOFIN, and FMBS. It was also revealed based on the study that there is a less positive correlation among experience, financial information, ORTOFIN, and FMBS. Simultaneously, it is evident from the study that age and experience are showing a negative relationship towards Personal planning $(\mathrm{r}=-0.040),(\mathrm{r}=-0.091)$, respectively. In short descriptive statistics, mean and standard deviation, and the correlations between variables under study are presented in Tables 2 . A significant positive correlation is found between ORTOFIN and Financial Information, Personnel Planning, and FMBS. Further, a negative correlation between age as well as experience towards personal planning. All other variables had significant positive correlations at the .001 level. 
Table 3

Model Summary

\begin{tabular}{|c|c|c|c|c|c|}
\hline Model & $\mathrm{R}$ & $\begin{array}{l}\mathrm{R} \\
\text { Square }\end{array}$ & $\begin{array}{l}\text { Adjusted } \\
\text { R Square }\end{array}$ & $\begin{array}{l}\text { Std. An error of } \\
\text { the Estimate }\end{array}$ & Model \\
\hline 1 & $.650^{\mathrm{a}}$ & .422 & .419 & 2.830 & 1 \\
\hline
\end{tabular}

Table 4

ANOVA

\begin{tabular}{llllll}
\hline Model & $\begin{array}{l}\text { Sum of } \\
\text { Squares }\end{array}$ & Df & $\begin{array}{l}\text { Mean } \\
\text { Square }\end{array}$ & F & Significance \\
\hline Regression & 1111.772 & 1 & 1111.772 & 138.861 & $.000^{\mathrm{b}}$ \\
Residual & 1521.207 & 190 & 8.006 & & \\
\hline Total & 2632.979 & 191 & & & \\
\hline
\end{tabular}

Dependent Variable: ORTOFIN Predictors: Constant FMBS

Regression analysis is statistically significant since $r^{2}$ is significant at $0.05 p=.005$. It is evident from the correlation analysis that a strong positive relationship exists with all the factors under study. So a regression analysis was taken with the highly significant factor FMBS. The summary results are shown in a tabulated form in Table 3. It is indicated through the results as 42 $\%$ of the variation in FMBS as an independent variable towards the factor ORTOFIN. In Table 3, it is mentioned. The $\mathrm{R}^{2}$ value is 0.422 , which is the contribution of FMBS. Further ANOVA technique was used to find the significance of factors understudy and found with significant $\mathrm{F}$ statics value 138.861, Table 11. So that it is evident that the regression model is adequate. The independent variable was tested and found significant for all variables. Thereby rejected the null hypothesis, and in short, the FMBS is having a significant contribution towards ORTOFIN.

\section{Table 5}

The results of regression analysis

\begin{tabular}{|c|c|c|c|c|c|}
\hline \multirow[b]{2}{*}{ Model } & \multicolumn{2}{|l|}{ Unstandardized Coefficients } & \multirow{2}{*}{$\begin{array}{l}\text { Standardized Coefficients } \\
\text { Beta }\end{array}$} & \multirow[b]{2}{*}{$\mathrm{t}$} & \multirow[b]{2}{*}{ Significance } \\
\hline & $\mathrm{B}$ & Std Error & & & \\
\hline 1 Constant & 8.616 & 1.134 & & 7.599 & .000 \\
\hline FMBS & .318 & .027 & .650 & 11.784 & .000 \\
\hline
\end{tabular}

Dependent Variable: ORTOFIN

Independent Variable: FMBS Financial Management Behavior Scale

One unit increase in FMBS will increase 0.318 units of ORTOFIN while other variables are kept constant. The correlation analysis found a significant positive correlation and a full model regression technique was used to find out the significance by keeping FMBS as an independent variable and ORTOFIN as a Dependent variable. Table 5 tabulates the results. The coefficient table is stating the significance of the predictors. FMBS is a significant predictor with a p-value of less than 0.05, i.e., . 000 . Thereby confirm that FMBS is a highly significant variable for ORTOFIN, and the regression model is adequate. This finding coincides with the result of Loix et al., (2005).

\section{Discussion and Conclusion}

This study has revealed Financial Management Behavior as a giant contributor to orientation and Finance, which is in line with the findings of Loix et al. (2005). Also, the factor of Personnel planning is resulting as a significant contributor towards ORTOFIN and the results are consistent with Chen and Volpe (1998). Thus, it provides a significant finding that the policymakers should focus on employed citizens' financial behavior, both men and women, towards various stages of their life to boost the economic conditions (Dew, 2007). This study also points out that the age group and ORTOFIN had a negative association, which reveals that they are not looking into the monetary benefits based on age. The employment status and experience of people show a negative association in this study. Technological advancement and fast lifestyles provide information to people at a quicker pace. However, different age group with employment experience are also struggling to understand how to manage finance and savings (Sulphey \& Nisa, 2014). Many studies have already made financial management and found a relationship between demographics and behavior towards finance (Xiao, Tang \& Shim, 2009). The finding of this research provides insights to organizations and policymakers to start communicating to the general public in terms of financial behavior as it acts as a significant contributor to an orientation towards finance. This is similar to Mahdzan and Tabiani, (2013) 's findings relating to the orientation towards finance. Minimal evidence has found in the previous studies in connection with financial behavior and Orientation towards finance, especially in GCC countries and specifically in Saudi Arabia. This research explored an area that is less explored and turned as a gap for literature, which succeeded with its findings from analysis relating to the significance.

\section{Acknowledgements}

This project was supported by Dean Scientific Research at Prince Sattam Bin Abdulaziz University under the research project number 2020/01/17109.

\section{References}

Alrabadi, D. W. H., Al-Abdallah, S. Y., \& Aljarayesh, N. I. A. (2018). Behavioral biases and investment performance: Does gender matter? Evidence from Amman Stock Exchange. Jordan Journal of Economic Sciences, 5(1), 77-92.

Asandimitra, N., Aji, T. S., \& Kautsar, A. (2019). Financial Behavior of Working Women in Investment Decision-Making. Information Management and Business Review, $11(2$ (I)), 10-20. 
Atchyuthan, N., \& Yogendrarajah, R. (2017). A study of investment awareness and preference of working women in Jaffna district in Sri Lanka. Asia Pacific Journal of Research, 1(L1), 2320-5504.

Bernheim, B.D., Garrett, D.M. and Maki, D.M. (2001), Education and saving: The long-term effects of high school financial curriculum mandates. Journal of Public Economics, 80, 435-465.

Bertrand, M. (2020, May). Gender in the Twenty-First Century. In AEA Papers and Proceedings, 110, 1-24.

Cabeza-García, L., Del Brio, E. B., \& Oscanoa-Victorio, M. L. (2019, November). Female financial inclusion and its impacts on inclusive economic development. In Women's Studies International Forum, 77, 102-300.

Chowdhury, E. K. (2009). Investment Behavior: A Study on Working Women in Chittagong. Nature, 70, 80.

Chen, H., \& Volpe R. P. (2002), Gender differences in Personal Financial Literacy among college students. Financial Services Review, 11 (2002), 289-307.

Dew, J.P. (2007), Two sides of the same coin? The differing roles of assets and consumer debt in marriage. Journal of Family and Economic Issues, 28, 89-104.

Doda, S., \& Fortuzi, S. (2015). Personal finance management helps in crisis management. Economics, Management, law: Problems and Prospects, 24.

Dohmen, T., Falk, A., Golsteyn, B. H., Huffman, D., \&Sunde, U. (2017). Risk attitudes in women investment

Esfandyar, S., RahnamayRoodposhti, F., Hashem, N., \& Reza, V. H. (2017). The objectives, strategies, and characteristics of individual investors in the Tehran stock exchange. Indonesian Capital Market Review, 11-26.

Faber, R.J., \& O'Guinn, T.C. (1988), Expanding the view of consumer socialization: A nonutilitarian mass-mediated perspective. In E.C. Hirschmann \& J. Sheth, N. (Eds.), Research in Consumer Behavior, 3, 49-77.

Fund, A. M. (2017). Arab Pension Systems.

Gitman, L. J., Joehnk, M. D., \& Billingsley, R. (2013). Personal financial planning. Cengage Learning.

Xiao J. J., \& Jeffrey D. (2011), The Financial Management Behavior Scale: Development and Validation, Journal of Financial Counseling and Planning, 22(1), 43-59

Joo, S. (2008), Personal financial wellness. In J.J. Xiao (Ed.), Advances in consumer finance behavior research, New York: Springer, 21-33.

Kanze, D., Huang, L., Conley, M. A., \& Higgins, E. T., (2018). We ask men to win and women not to lose: Closing the gender gap in startup funding. Academy of Management Journal, 61(2), 586-614.

Lee, I., \& Shin, Y. J. (2018). Fintech: Ecosystem, business models, investment decisions, and challenges. Business Horizons, 61(1), 35-46.

Loix, E., Pepermans, R., Mentens, C., Goedee, M. and Jegers, M., (2005), Orientation toward Finances: Development of a Measurement Scale, The Journal of Behavioral Finance, 6(4), 192-201.

Lusardi, A. \& Mitchell, O.S. (2007), Financial Literacy and Planning: Implications for Retirement Wellbeing, Working Paper, Pension Research School, The Wharton School.

Munohsamy, T. (2015). Personal Financial Management.

Murphy, D. S., \&Yetmar, S. (2010). Personal financial planning attitudes: a preliminary study of graduate students. Management Research Review.

Perry (2005), Fischer Black, and the revolutionary idea of finance, John Wiley \& Sons, Inc., pp xv, 374. ISBN-13 978-0-471-45732-9.

Ramanujam, V., \& Leela, L. (2016). A study on investment literacy towards investment decision-making behavior of working women. International Journal in Management \& Social Science, 4(5), 28-34.

Rekha, G., \& Vishnupriya, R. (2019). A Study on Investment Pattern among Working Women. Children, 148(1), 5.

Salim, A., \& Khan, S. (2020). The effects of factors on making investment decisions among Omani working women. Accounting, 6(5), 657664.

Salim, A., Riyas, M., \& Nair, A.B. (2019). A study on the motives of Omani teachers' income distribution towards different investment avenues. Journal of Advanced Research in Dynamical and Control Systems, 11, ( Sp- 08), (2181-2188)

Steelyana, W. (2012, May). Working Women and Investment Behavior. In 3rd IMHA (International Conference on Management, Hospitality, and Accounting) at Bina Nusantara University, Jakarta, Indonesia.

Sood, D., \& Kaur, N. (2015). A study of saving and investment pattern of salaried class people with special reference to chandigarh (India). International Journal of Research in Engineering, IT \& Social Sciences, 5(2), 1-15.

Sulphey, M. M. \& Salim, A. (2020). Development of a tool to measure social entrepreneurial orientation", Journal of Entrepreneurship in Emerging Economies, 13(3) https://doi.org/10.1108/JEEE-07-2019-0099

Sulphey, M. M., \& Nisa, S. (2014). ORTOFIN: testing of ORTOFIN scale in the Indian context. Journal of Applied Management and Investment, 3(4), 257-264. https://papers.ssrn.com/sol3/papers.cfm?abstract id=2537664

Sulphey, M.M. \& Nisa, S. (2014), ORTOFIN: Testing of ORTOFIN Scale in the Indian Context, Journal of Applied Management and Investments, 3(4), 257-264.

Walker, M. (1995), The Psychology of Gambling, Butterworth-Heinemann, London.

Wärneryd, K. E. (1999), The Psychology of Saving: A Study on Economic Psychology, Edward Elgar, London, 22(2), 295-299.

Wärneryd, K.E. (2001), Stock Market Psychology. How People Value and Trade Stocks, Edward Elgar, Cheltenham, UK, 23(4), 546-548.

Xiao, J.J., Tang, C., \& Shim, S. (2009), Acting for happiness: Financial behavior and life satisfaction of college students. Social Indicators Research, 92, 53-68.

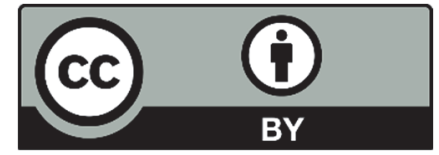

(C) 2021 by the authors; licensee Growing Science, Canada. This is an open access article distributed under the terms and conditions of the Creative Commons Attribution (CC-BY) license (http://creativecommons.org/licenses/by/4.0/). 